\title{
Consumer Responses to Salient Image Attributes in Restaurant Selection in Southern Gauteng, South Africa
}

\author{
Prof. M. Dhurup \\ Faculty of Management Sciences: Vaal University of Technology \\ Private Bag X021, Vanderbijlpark, 1900, South Africa \\ Email: royd@vut.ac.za, Tel: 016(930) 6886, Fax to email: 0866265319 \\ Mr C. Mafini \\ Faculty of Management Sciences: Vaal University of Technology \\ Private Bag X021, Vanderbijlpark, 1900, South Africa \\ Email: chengedzai@hotmail.com* \\ Mr. J. Malan \\ 25 Gill Street, New Plymouth, New Zealand, 4310 \\ Jmalan@transfieldworley.co.nz
}

\section{Doi:10.5901/mjss.2013.v4n3p283}

\section{Abstract}

Restaurant choice may be influenced by various factors. Literature identifies considerable variations in the attributes that influence restaurant patronage. The study reports on salient image attributes that influence restaurant patronage behavior and examines the relationship between image attributes on satisfaction and loyalty. The study adopted a quantitative approach in which a structured questionnaire was used to survey 247 respondents who were selected using non-probability convenience sampling. Six dimensions measuring image attributes were found to be applicable within restaurants. A restaurant's atmospherics or ambience, service personnel, pricing, payment options, comfort and overall cleanliness of the environment were identified as key factors that customers use when choosing restaurants. Four factors namely; atmospherics, employee service, pricing and cleanliness showed a strong predictive relationship with satisfaction. The results obtained indicated strong correlations between satisfaction and loyalty. Furthermore, atmospherics, employee service and restaurant cleanliness showed strong predictive relationships with satisfaction. Satisfaction in turn showed a strong predictive relationship with loyalty. The instrument can be used as a diagnostic tool for uncovering broad areas of restaurant salient image attributes, shortfalls and strengths by undertaking periodic measurements of image enhancement strategies.

Keywords: Image, satisfaction, loyalty, atmospherics, quality, comfort.

\section{Introduction}

An emerging and dominant trend in most parts of the world is that more people are consuming meals outside their homes (Kara, Kaynak \& Kucukemiroglu, 1997). Mawson and Fearne (1996) noted that the main reason for such consumption behaviours resides in the changing demographics, rising incomes, increased demand for convenience foods and an increase in leisure activity. Koo, Tao and Yeung (1999) further submit that eating out has become a necessity in a fast, pressurised and often affluent society, making it either an important social or business occasion.

Depending on the purpose of eating out, consumers subconsciously evaluate a complex set of image attributes (such as location, price, service quality, atmosphere and interior design) before making their preferences among restaurants. The importance of restaurant attributes, though unique, may come into play in choice decisions (Koo et al., 1999). Yun and Good (2007) posit that image is a critical component in restaurant choice, since image attributes can evoke cognitive perceptions and emotional responses which comprise a combination of functional and psychological factors that consumers may unconsciously or consciously connect with their restaurant experience. In essence, utility and emotional aspects in restaurant selection become essential. 
Consumers tend to conceive the concept of choice as an act of decision-making and that choice is not only available, but also made (Clarke et al, 2004). This aspect provides credence to an understanding of consumers' desires and what makes them return to restaurants (Soriano, 2002). In addition, consumers' choice of restaurants is not solely based on image attributes or the type of 'products' offered, but by the experiences offered or expected, whether it is psychological or emotional (Robinson, Abbott \& Shoemaker, 2005).

Within the restaurant context, there is a growing need to evaluate the true drivers of image attributes and restaurant choice behaviour (Kivela, Inbakaran \& Reece, 1999). To better understand consumers' restaurant experience it is necessary to define, examine and substantiate the connections between customers' expectations of restaurant attributes and their actual experience of the restaurants' attributes.

Restaurants were chosen as an object of the study because of the growing income, approximately R1.592m generated in 2012 by restaurants in South Africa and their contribution to employment (approximately 93000 jobs) and to the Gross National Product (approximately 1.67\%) of South Africa (Statistics South Africa, 2013). In addition, the Tourism and Hospitality Industry in South Africa as a whole has been characterised by poor training and development, limited career progression and low salaries (Moolman, 2011). To address these challenges and to accelerate the responsible growth of South African Tourism, the Minister of Tourism identified employment and skills training of employees within the industry as a priority in order to enhance the provision of high quality service to consumers (Republic of South Africa National Department of Tourism, 2011).

\subsection{Image attributes}

Soriano (2002) is of the view that the most important question for management to ask is which of the attributes are critical for customers who return to a restaurant. It has also been reported in literature that customers' patronage behaviour towards a particular restaurant is dependent on its image; thus the more favourable the restaurant image, the higher the acceptability of the restaurant to a customer (Bloemer \& Ruyter, 1998).

Defining restaurant image is far from easy. Martineau (1958:47) was one of the earlier scholars to offer the following description of store image: "it is the way in which a store is defined in the shopper's mind." Store image consists of a complex blend of tangible and intangible elements made up of functional and psychological attributes (Porter \& Clycomb, 1997; Thompson \& Chen, 1998; Erdem, Oumlil \& Tuncalp, 1999; Burt \& Carralero-Encinas, 2000; Hu \& Jasper, 2006; Dhurup \& Oosthuyzen, 2010). Image is expressed as a function of the salient attributes of a particular restaurant that is evaluated and weighed against other restaurants (Bloemer \& Ruyter, 1998). Porter and Claycomb (1997) concluded that restaurant image is an individual's cognitions and emotions, inferred from perceptions or memory inputs attached to a particular restaurant, which represent what that restaurant signifies to an individual. Pedraja and Yagüe (2001) are of the view that while the need to patronise a restaurant may be motivated by various reasons, individuals still have to search for information on a restaurant in order to be able to compare the existing alternatives and make the best patronage decision. For the purpose of this study, store image or restaurant image is defined as the various attributes that contribute towards the 'persona' of a restaurant.

By merely providing appropriate restaurant attributes is not enough to satisfy consumers and guarantee dining loyalty. Maintaining the quality of these attributes is a difficult task and critical for survival in competitive environments (Ko \& Kincade, 1997). Kivela (1997) suggests that establishing the importance of an attribute may not be a good predictor of restaurant choice because there may be several competing restaurants that offer an equally attractive range of attributes that are regarded as equally important. Thus, it is the importance of an attribute coupled with the perceived difference among competing restaurants that determines choice criteria and provides the basis for predicting post-dining behaviour intention. A consumer may perceive that one restaurant is more desirable than another, solely because of the difference in restaurant image (Tepeci, 1999).

Restaurant image is composed of factual and emotional material - customers may hold a factually based opinion that enables them to summarise their feelings about a restaurant and to compare one restaurant with another. A differential advantage may be achieved if the restaurant image is matched with the diner's self-image. This match-making is expected to make the customers dine in restaurants that have a good image (Ness, Gorton \& Kuznesof, 2002). Consumers also form impressions about restaurants which have a significant impact on patronage and frequency patterns (Darley \& Lim, 1999). Thus, restaurant-specific attitudes and general attitudes toward the type of restaurant influence dining frequency.

Within the restaurant environment, customers can be exposed to numerous stimuli, all of which potentially affect how consumers react, what they consume, and their satisfaction with the service experience (Herrington \& Capella, 
1996). Jin and Kim (2003) stated that considerable research efforts have been directed to identifying important restaurant attributes that affect consumers' restaurant choice and patronage decisions. The authors revealed that restaurant attributes include factors such as service quality, price, value, restaurant personnel (e.g. waiters), waiter service, service delivery, physical facilities (such as layout, architecture and convenience), promotional programmes and store atmosphere (which represents a customer's feeling of warmth, acceptance or ease in the restaurant).

\section{Problem Statement}

Kivela, et al. (1999) revealed that customers' eating-out needs are linked with restaurant food quality, service quality, location, type of cuisine, and staff attitudes. Soriano (2002) established that good food, service, location, variety and staff attitude are inadequate to attract and retain consumers and that emotional aspects may also play a role in restaurant preferences. Consequently, various image attribute factors come into play in restaurant choice selection.

In the understanding of image attributes and choice behaviour, Kara et al. (1997) established that there has been a limitation in past research on consumer preferences which have been limited to the description of the characteristics of restaurant consumers. Within a South African setting, Newberry, Klemz and Boshoff (2003) affirm that a substantial amount of research presented in services marketing has focused on describing or predicting purchase behaviour. Furthermore, with regard to restaurant choice, considerable variations exist relating to the number of attributes used in different studies pertaining to restaurant choice criteria. The variety of attributes identified by researchers and their findings acknowledge that not all restaurant attributes are equally prominent in affecting choice (Paulins \& Geistfeld, 2003). Although an overwhelming number of research studies have found a positive relationship between customer satisfaction and loyalty in various service settings (Han, Back \& Barrett, 2009; Moolman, 2011), some researchers (Skogland \& Siguan, 2004; Chow, Lau, Lo, Sha \& Yun, 2007) found a weak relationship between the two variables. There is limited research particularly in the restaurant sector that examined the roles image attributes play in developing customer satisfaction and in forming customer loyalty (Han \& Ryu, 2009). Therefore, the purpose of the study is to determine salient image attributes that influence restaurant patronage behavior. The secondary purpose of the study is to examine the relationship between the salient image attributes on satisfaction and loyalty.

\section{Materials and Methods}

The study utilised a quantitative research approach so that the data could be quantifiable in order to apply some form of statistical analysis (Malhotra, 2007). This approach was chosen because the study was descriptive and inferential in nature.

\subsection{Target Population}

The target population was restricted to respondents residing in Southern Gauteng, South Africa. The population comprised individuals, male and female, eighteen years and older. Respondents over the age of eighteen years were chosen because of the alcohol legislation in South Africa. Alcohol by law cannot be served or sold to anyone under the age of eighteen (Republic of South Africa, 2004).

\subsection{The Sample}

It is often difficult and expensive to gain access to truly accurate, or representative, sampling frames especially in consumer research (Hair, Bush \& Ortinau, 2000). Due to the nature of this study, it was not possible to obtain a list of customers. For this reason the study focused on set locations, that is restaurants in different areas. Therefore, the survey location was used as a sample frame. The restaurants that were surveyed belonged to three chain restaurants in South Africa who specialised in a 'sit down' dining facility.

The study made use of a non-probability convenience sampling technique. Three hundred respondents were approached to participate in the study of which 38 potential respondents refused to participate and 15 questionnaires that were incomplete were discarded. Two hundred and forty seven questionnaires were coded and eventually used for the analysis. 


\subsection{Data collection}

A structured questionnaire was administered. In order to randomise the data collection, special attention was given to age groups and gender distribution. The questionnaire contained sections for demographic information, restaurant attributes, satisfaction and loyalty. The questionnaire was divided into four sections. Section A constituted questions on demographic variables. In Section A, dichotomous and multiple-choice questions were used. Section B consisted of Likert scale items on restaurant image attributes. Section B comprised a series of seven-point Likert scales which was anchored as follows: $1=$ strongly disagree and $7=$ strongly agree. Section $C$ and section $D$ also comprised the same format of questions but anchored on a 5 -point scale with $1=$ definitely unlikely and $5=$ definitely likely on aspects of restaurant satisfaction and loyalty.

\section{Results}

Data analysis comprised four phases namely, sample composition, an assessment of the underlying dimensions of restaurant image attributes by using exploratory factor analysis, correlations and regression analysis.

\subsection{Sample Composition}

There were slightly more female respondents $(51 \% ; n=126)$ than males $(49 \% ; n=121)$ in the sample. The highest percentage of respondents was between the 26 to 35 years age range (32\%; $n=80)$, followed by 18 to 25 years (20\%; $n=50)$ and 36 to 45 years (17\%; $n=41)$ respectively. The age group 65 years and older constituted approximately $6 \%$ $(n=15)$ of the sample. In terms of the marital status, $64 \%(n=159)$ of the sample were married and $32 \%(n=80)$ were single. Those respondents that were separated constituted $3 \%(n=8)$ of the sample. Majority of the respondents $(25 \%$; $n=61$ ) earned a monthly income between R5001 to R10 000. This was followed by those who earned between R10 000 to R15 000 (19\%; n=48) and those who earned between R15 001 to R20 000 (14.6\%; n=36). The reasons for dining were classified as follows: social (61.94\%; $n=153)$, celebration (14.98\%; $n=37)$; convenience $(13.77 \% ; n=34)$ and business $(6.88 \% ; n=17)$. A small percentage $(2.02 \% ; n=5)$ dine because they have extra money or dine because of extra time to spend $(0.4 \% ; n=1)$. Out of the 247 respondents, $19.03 \%(n=47)$ have chosen restaurants on the basis of the atmosphere and ambience, further $18.62 \%(n=46)$ chose restaurants for the cuisine and variety of foods served, $17.41 \%(n=43)$ reported that they chose the restaurant because of its service, whilst $12.55 \%(n=31)$ chose a particular restaurant because of its reputation, price/value and location.

\subsection{Factor Analysis}

The appropriateness of factorability on the data set was statistically determined using the Kaiser-Meyer-Olkin (KMO) test of sampling adequacy as well as the Bartlett's Test of Sphericity. The KMO test of sampling adequacy is an index used to measure the appropriateness of the factor analysis procedure. Moderate to high KMO values (between 0.5 and close to 1.0) indicate that the data is appropriate for factor analysis (Malhotra, 2007). The Kaiser-Meyer-Olkin measure of sampling adequacy (KMO) was 0.914 indicating that the factor analysis was appropriate for the data set. The Bartlett's Test of Sphericity was performed on the data to test if the variables are uncorrelated (Malhotra, 2007). The approximate chi square for the data set was 5501.754 with 465 degrees of freedom (df) which is significant at $p<0.0000$ thus indicating that the correlations among the variables and the factor analysis procedure are appropriate for the data set.

The application of the factor analysis procedure using a varimax rotation method resulted in six components being identified as important image attributes. The final factor structure is reported in Table 1.

Table1: Factor loading matrix

\begin{tabular}{|c|c|c|c|c|c|c|}
\hline \multicolumn{7}{|c|}{ Factors } \\
\hline Variables & $\begin{array}{c}\text { Factor } \\
1\end{array}$ & $\begin{array}{c}\text { Factor } \\
2\end{array}$ & $\begin{array}{c}\text { Factor } \\
3\end{array}$ & $\begin{array}{c}\text { Factor } \\
4\end{array}$ & $\begin{array}{c}\text { Factor } \\
5\end{array}$ & $\begin{array}{c}\text { Factor } \\
6\end{array}$ \\
\hline The displays in this restaurant are appealing & 0.677 & 0.120 & 0.183 & 0.234 & -0.069 & 0.084 \\
\hline Interior walls in this restaurant are attractive & 0.772 & 0.138 & 0.112 & 0.181 & 0.049 & 0.127 \\
\hline This restaurant has an appealing exit & 0.683 & 0.223 & 0.158 & 0.164 & -0.013 & 0.128 \\
\hline The interior of this restaurant's design is exciting & 0.780 & 0.253 & -0.004 & 0.048 & 0.117 & -0.006 \\
\hline
\end{tabular}




\begin{tabular}{|c|c|c|c|c|c|c|}
\hline \multicolumn{7}{|c|}{ Factors } \\
\hline Variables & \begin{tabular}{|c|} 
Factor \\
1
\end{tabular} & \begin{tabular}{|c|} 
Factor \\
2
\end{tabular} & $\begin{array}{c}\text { Factor } \\
3\end{array}$ & \begin{tabular}{|c|} 
Factor \\
4
\end{tabular} & \begin{tabular}{|c|} 
Factor \\
5
\end{tabular} & $\begin{array}{c}\text { Factor } \\
6\end{array}$ \\
\hline The exterior of this restaurant's design is attractive & 0.738 & 0.143 & 0.072 & 0.101 & 0.057 & -0.005 \\
\hline The overall design of this restaurant is interesting & 0.798 & 0.184 & 0.011 & 0.047 & 0.195 & 0.108 \\
\hline The overall layout of this restaurant provided me with comfort & 0.625 & 0.231 & 0.156 & 0.159 & 0.267 & 0.127 \\
\hline This restaurant is painted in attractive colours & 0.743 & 0.162 & 0.156 & 0.034 & 0.077 & 0.180 \\
\hline This restaurant's architecture gives it an attractiv & 0.799 & 0.024 & 052 & 0.050 & 0.178 & 0.077 \\
\hline This restaurant is decorated in a trendy fashion & 0.794 & 0.095 & 192 & 0.046 & 0.074 & 0.043 \\
\hline The internal displays in this restaurant is appealing & 0.852 & 0.163 & 0.000 & 0.005 & 0.165 & 0.043 \\
\hline This restaurant is decorated in an att & 0.882 & 0.105 & 0.106 & 0.084 & 0.114 & 0.009 \\
\hline This restaurant is attractive & 0.764 & 0.252 & 0.112 & 0.101 & 0.191 & 0.073 \\
\hline Emp & 0.203 & 0.780 & 0.181 & 0.137 & 0.157 & 0.047 \\
\hline Emp & 0.220 & 0.791 & 223 & 0.120 & 0.114 & -0.020 \\
\hline Emp & 205 & 0.735 & 128 & 0.164 & 0.126 & 0.095 \\
\hline Employe & 0.278 & 0.752 & 0.049 & 0.104 & 0.072 & 0.191 \\
\hline This restaurant offers high quality service & 0.257 & 0.695 & 0.096 & 0.066 & 0.326 & -0.034 \\
\hline Prices of meals are affordable & 0.056 & 0.125 & 0.840 & 0.081 & 0.130 & 0.094 \\
\hline Pric & 103 & 0.129 & 776 & 0.010 & 0.125 & 0.074 \\
\hline Prices & .182 & 0.385 & 0.552 & 0.085 & 0.160 & -0.088 \\
\hline Prices of $\mathrm{t}$ & 0.149 & 0.144 & 0.828 & 0.118 & 0.140 & 0.001 \\
\hline This restaurant has low priced specials & 0.161 & 0.017 & 0.648 & 0.141 & -0.186 & 0.022 \\
\hline This restaurant has plenty of knee room in the seats & 0.164 & 0.148 & 0.153 & 0.875 & 0.092 & 0.114 \\
\hline There is plenty 0 & 0.203 & 0.163 & 0.082 & 0.882 & 0.091 & 0.091 \\
\hline Ther & 0.147 & 0.191 & 0.159 & 0.758 & 0.268 & 0.104 \\
\hline This $r$ & 0.244 & 0.321 & 0.145 & 0.242 & 0.732 & 0.085 \\
\hline This restaur & 0.335 & 0.335 & 0.148 & 0.200 & 0.646 & 0.211 \\
\hline This restaurant maintains clean restrooms & 0.202 & 0.179 & 0.070 & 0.107 & 0.751 & -0.031 \\
\hline This restaurant accepts cash cards for payn & 0.167 & 0.088 & 0.077 & 0.103 & 0.084 & 0.902 \\
\hline This restaurant accepts credit cards for payment & 0.214 & 0.077 & 0.032 & 0.156 & 0.026 & 0.865 \\
\hline Eigenvalues & 12.147 & 3.215 & 2.054 & 1.889 & 1.372 & 1.112 \\
\hline Variance (\%) & 26.954 & 12.134 & 10.095 & 8.273 & 6.918 & 5.915 \\
\hline Cumulative $\%$ of variance & 26.954 & 39.088 & 49.183 & 57.456 & 64.374 & 70.288 \\
\hline
\end{tabular}

\subsection{Correlations}

Correlations were computed in order to ascertain the association of the six image attributes with satisfaction and loyalty. The results of the Pearson correlation coefficients revealed that statistically significant positive correlations existed between all six dimensions of restaurant image attributes and satisfaction. The correlations for the six restaurant image attribute dimensions and satisfaction ranged from $r=0.174$ to $r=0.493$ significant at a 0.01 or 0.05 level, indicating that restaurant image is positively correlated with satisfaction. The correlations between satisfaction and loyalty also reported strong positive linear relationships $r=0.827$ at the 0.01 level of significance indicating that the satisfaction with restaurants influences customer future loyalty to a restaurant. Table 2 reports on the correlations between the six factors with satisfaction and loyalty. High correlation coefficients reflect strong level of association between variables (Hair et al., 2000).

Table 2: Correlations of Six Factors with Satisfaction and Loyalty

\begin{tabular}{|l|c|c|c|c|c|c|c|c|}
\hline Factors & $\begin{array}{c}\text { Factor 1 } \\
\text { Atmospherics }\end{array}$ & $\begin{array}{c}\text { Factor 2 } \\
\text { Service }\end{array}$ & $\begin{array}{c}\text { Factor 3 } \\
\text { Pricing }\end{array}$ & $\begin{array}{c}\text { Factor 4 } \\
\text { Comfort }\end{array}$ & $\begin{array}{c}\text { Factor 5 } \\
\text { Cleanliness }\end{array}$ & $\begin{array}{c}\text { Factor 6 payment } \\
\text { options }\end{array}$ & Satisfaction & Loyalty \\
\hline Factor 1 Atmospherics & 1 & $.515^{* *}$ & $.345^{* *}$ & $.378^{* *}$ & $.506^{* *}$ & $.332^{* *}$ & $.433^{* *}$ & $.396^{* *}$ \\
\hline Factor 2 Service & & 1 & $.416^{* *}$ & $.418^{* *}$ & $.589^{* *}$ & $.236^{* *}$ & $.493^{* *}$ & $.434^{* *}$ \\
\hline Factor 3 Pricing & & & 1 & $.330^{* *}$ & $.335^{* *}$ & $.161^{*}$ & $.377^{* *}$ & $.401^{* *}$ \\
\hline Factor 4 Comfort & & & & 1 & $.458^{* *}$ & $.313^{* *}$ & $.233^{* *}$ & $.256^{* *}$ \\
\hline Factor 5 Cleanliness & & & & & 1 & $.256^{* *}$ & $.483^{* *}$ & $.453^{* *}$ \\
\hline Factor 6 Payment & & & & & & 1 & $.174^{* *}$ & $.239^{* *}$ \\
\hline
\end{tabular}




\begin{tabular}{|l|c|c|c|c|c|c|c|c|}
\hline Satisfaction & & & & & & & 1 & $.827^{* *}$ \\
\hline Loyalty & & & & & & & & 1 \\
\hline Means & 5.11 & 5.61 & 5.11 & 5.27 & 5.72 & 6.47 & 4.20 & 4.22 \\
\hline
\end{tabular}

${ }^{\star \star}$ Correlations $a^{\star \star}$ Correlations are significant at the 0.01 level (2-tailed). ${ }^{*}$ Correlations are significant at the 0.05 level. Restaurant image attributes were measures on a 7-point Likert scale. Satisfaction and loyalty were measured on a 5-point Likert scale.

\subsection{Regression}

The results of the factor analysis provided empirical support for six factors. Of interest was the relationship between the six factors, satisfaction and loyalty. A regression analysis was undertaken between the six factors with satisfaction and loyalty. The result of the regression model with satisfaction as the dependent variable and the six dimensions as independent variables is presented in Table 3. In terms of the relationship between the individual dimensions and satisfaction, the $\mathrm{R}^{2}=0.35$ suggests that the restaurant dimensions explained approximately $35 \%$ of the variance in the customers' overall loyalty.

Table 3: Regression Analyses between Six Factors with Satisfaction

\begin{tabular}{|l|c|c|c|}
\hline \multicolumn{4}{|c|}{ Dependent variable: satisfaction } \\
\hline Dimensions (Independent variable) & Beta & $\mathrm{t}$ & $\mathrm{p}$-value \\
\hline Factor 1: Restaurant atmospherics & 0.165 & 3.704 & 0.013 \\
\hline Factor 2: Employee service & 0.229 & 2.500 & 0.001 \\
\hline Factor 3: Pricing & 0.172 & 3.248 & 0.004 \\
\hline Factor 4: Comfort & -0.98 & 2.917 & 0.117 \\
\hline Factor 5: Restaurant cleanliness & 0.251 & -1.575 & 0.000 \\
\hline Factor 6: Payment options & 0.004 & 3.611 & 0.590 \\
\hline $\mathrm{R}=0.590 \quad \mathrm{R}^{2}=0.348 \quad$ Adjusted $\mathrm{R}^{2}=0.332$ & $\mathrm{p}<0.05 \quad \mathrm{~F}=21.365$ & Sig. F Change 0.000 \\
\hline
\end{tabular}

The regression analysis between the six dimensions and loyalty is presented in Table 4. In terms of the relationship between the individual dimensions and the overall loyalty rating, the $\mathrm{R}^{2}=0.31$ suggests that the restaurant dimensions explained approximately $31 \%$ of the variance in the customers' overall loyalty.

Table 4: Regression Analyses between Six Factors with Loyalty

\begin{tabular}{|l|c|c|c|}
\hline \multicolumn{4}{|c|}{ Dependent variable: Loyalty } \\
\hline Dimensions (Independent variable) & Beta & $\mathrm{t}$ & $\mathrm{p}$-value \\
\hline Factor 1: Restaurant atmospherics & 0.116 & 1.720 & 0.870 \\
\hline Factor 2: Employee service & 0.143 & 1.985 & 0.048 \\
\hline Factor 3: Pricing & 0.227 & 3.751 & 0.000 \\
\hline Factor 4: Comfort & -0.590 & -0.924 & 0.356 \\
\hline Factor 5: Restaurant cleanliness & 0.238 & 3.336 & 0.001 \\
\hline Factor 6: Payment options & 0.088 & 1.513 & 0.132 \\
\hline $\mathrm{R}=0.560 \quad \mathrm{R}^{2}=0.313 \quad$ Adjusted $\mathrm{R}^{2}=0.296$ & $\mathrm{p}<0.05$ & $\mathrm{~F}=18.262$ & Sig. F Change 0.000 \\
\hline
\end{tabular}

Finally, the regression analysis of the six restaurant image dimensions and satisfaction with loyalty is presented in Table 5. In terms of the relationship between the individual dimensions and the overall loyalty, the adjusted $R^{2}=0.70$ suggests that the restaurant dimensions and satisfaction explained approximately $70 \%$ of the variance in the customers' overall loyalty.

Table 5: Regression analysis of Six Factors and Satisfaction with Loyalty

\begin{tabular}{|l|c|c|c|}
\hline \multicolumn{4}{|c|}{ Dependent variable: Loyalty } \\
\hline Dimensions (Independent variables) & Beta & $\mathrm{t}$ & $\mathrm{p}$-value \\
\hline Factor 1: Restaurant atmospherics & -0.011 & -0.242 & 0.809 \\
\hline Factor 2: Employee service & -0.033 & -0.684 & 0.495 \\
\hline Factor 3: Pricing & 0.094 & 2.318 & 0.021 \\
\hline
\end{tabular}




\begin{tabular}{|l|c|c|c|}
\hline Factor 4: Seating comfort & 0.017 & 0.394 & 0.694 \\
\hline Factor 5: Restaurant cleanliness & 0.044 & 0.911 & 0.363 \\
\hline Factor 6: Payment options & 0.085 & 2.222 & 0.027 \\
\hline Satisfaction & 0.773 & 17.689 & 0.000 \\
\hline $\mathrm{R}=0.838 \quad \mathrm{R}^{2}=0.703 \quad$ Adjusted $\mathrm{R}^{2}=0.694 \quad \mathrm{p}<0.05$ & $\mathrm{~F}=80.692 \quad$ Sig. F Change 0.000 \\
\hline
\end{tabular}

\section{Discussion}

Factor one, labeled restaurant atmospherics, comprised thirteen variables and accounted for $39.18 \%$ of the variance. The items that loaded onto the factor relate mainly to the level of restaurant ambience and how it influences the restaurant selection process. The items that loaded on this factor include interior design, layout and architecture. The term 'atomspherics' was first coined by Kotler (1974:48) who described it as the "silent language" which is analysed through the senses and ultimately influences the customers' emotions. Consistent with the results of this study, Hu and Jasper (2006) found that the social cues (the environment atmosphere) in a restaurant environment have a positive effect on the customers' perception of restaurant image. A study conducted byHueng and Gu (2012) also found that 'store induced' feelings from the restaurant atmosphere aroused an individuals' excitement and emotion in an environment.

Several other studies confirmed similiar factors that affect the restaurant selection process. Some of these are design and concept (Soriano, 2002), ambience and atmosphere (Kivela, 1997; Milliman \& Fugate 1993). Most of the aforementioned authors found that these factors play an important role in the restaurant selection or rejection process as well as the customer's perceptions towards the restaurant. Koo et al. (1999) concluded that customers do not evaluate each restaurant attribute individually but use the attribute and image information holistically in the selection process.

The second factor labeled employee service, comprised five variables and accounted for $10.37 \%$ of the variance. The variables that comprised the employee service aspect relate to employee willingness to assist patrons, personal attention extended by employees and their efficiency and the quality of service provided. Employees' willingness to help, their personal attention given to their customers and their efficiency in service delivery creates positive images in the minds of customers. There appears to be consensus that service employees within a restaurant environment seem to contribute to an image of a restaurant (Pratten, 2003; Hu \& Jasper, 2006). For example, a perfectly prepared meal could be poorly received by customers if it is shoddly served. Service employees and more especially waiters are the primary contact between the customer and the restaurant and their performance seem to have a major impact on the level of customer enjoyment.

The third factor labeled pricing, comprised five variables and accounted for $6.62 \%$ of the variance. Grobler's (2008) study also attained similar results, thus providing some substantiantion that price is an essential factor that contributes to the image of a restaurant and choice decisions. Research into consumer studies with regard to pricing is ubiquitous in marketing literature because of its presence in all buying situations (Moore \& Carpenter, 2006; Andaleeb \& Conway, 2006). Consumers often perceive price in negative and positive perspectives. From a negative perspective, price is perceived purely as an economic sacrifice. When prices of meals are perceived as a positive cue, it signals quality, prestige or status of the restaurant to the consumer. However, the linkage of price to store choice tends to be mixed (Seiders \& Costley, 1994; Yavas, 2003). The price of restaurant meals varies according to the type of restaurant. If the price is high, customers are likely to expect high quality. If the price is low, customers may question the ability of the restaurant to deliver product and service quality (Andaleeb \& Conway, 2006).

The fourth factor labelled comfort, comprised three variables and accounted for $6.09 \%$ of the variance. The layout and seating should minimise crowding in order to create a favourable impression among guests (Countryman \& Jang, 2006). Some seats may be comfortable/uncomfortable because of their design or conditions (new versus deteriorating; padded versus non-padded; bench seats as versus seats with backs). Seats may also be comfortable or uncomfortable, due to their proximity to other seats as customers may be physically and psychologically uncomfortable if they are forced to sit too close to other customers. Previous research related to perceived crowding (Wakefield \& Blodgett, 1996) suggests that cramped seating is likely to be perceived as displeasing and of a poor quality. The amount of space between rows of seats is also an important dimension, as it affects the ease with which customers may exit their seats to use ancillary service areas such as restrooms.

The fifth factor labelled restaurant cleanliness, comprised three variables and accounted for $4.42 \%$ of the variance. Cleanliness is a facet of the general ambience of the environment pertaining to the five senses. Even when consciously noted, they may still affect people's emotional wellbeing, perception, attitudes and behaviours. The ambient environment is a gestalt concept, composed of literally hundreds of design elements and details that have to work together to create a mood that is perceived and interpreted by customers (Bitner, 1992). Thus, if the cleanliness of a restaurant is perceived 
as negative, these negative emotions may create avoidance behaviours which may result in consumers not visiting the restaurant in the future. In a study undertaken by Lee, Ibrahim and Hsueh-Shan (2005), cleanliness was ranked the most important over other image attributes in patronage decisions.

The six factor labelled payment options, comprised two variables and accounted for $3.58 \%$ of the variance. This is a new factor that has emerged in the study and relates to cash and credit card usage as a means of payment. Payment methods have a very small influence on the dining decision but are still an important factor to consider. Most restaurants have electronic fund transfer point of sale (EFTPoS) systems in place. The latest payment technology needs to be implemented, where the EFTPoS machine is wireless. This allows the customer to remain seated while making payment. It increases the satisfaction levels by allowing the customers to enjoy their dining experience until the end.

In terms of the relationship between the individual dimensions and the overall satisfaction rating, the dimensions atmospherics (F1), employee service (F2), pricing (F3) and restaurant cleanliness (F5), were statistically significant at $p<$ 0.05. Comfort (F4) and payment options (F6) showed no predictive relationship with overall restaurant satisfaction. Satisfaction was primarily predicted by factor 5 : restaurant cleanliness $(\beta=0.251)$, factor 2 : employee service $(\beta=0.229)$, factor 3: pricing $(\beta=0.172)$ and factor 1: restaurant atmospherics $(\beta=0.165)$, ranging from the highest to the lowest contributions. Aspects such as good architecture and layout, efficiency and quality of employee service, competitive pricing, a clean and hygienic environment were effective in influencing customers' overall restaurant satisfaction.

In terms of the relationship between the six dimensions and loyalty the dimensions employee service (F2), pricing (F3) and restaurant cleanliness (F5) were statistically significant at $p<0.05$. Restaurant atmospherics (F1), comfort (F4) and payment options (F6) showed no predictive relationship with overall restaurant loyalty. Loyalty was primarily predicted by factor 5 : restaurant cleanliness $(\beta=0.238)$, factor 3 : pricing $(\beta=0.227)$ and factor 2 : employee service $(\beta=$ 0.143 ) ranging from the highest to the lowest contributions. Aspects such as a clean and hygienic environment, competitive pricing and the efficiency and quality of employee service were effective in influencing customers' overall restaurant loyalty.

In terms of the relationship between the six restaurant image attribute dimensions and satisfaction with overall loyalty rating, the dimensions satisfaction, pricing (F3) and payment options (F6) were statistically significant at $p<0.05$. Comfort (F4) and restaurant cleanliness (F5) showed a moderate relationship with overall restaurant loyalty. Satisfaction showed the strongest association with overall restaurant loyalty. The beta coefficients indicate that restaurant atmospherics (F1) and employee service (F2) did not significantly contribute to the prediction of loyalty. Loyalty was primarily predicted by satisfaction ( $\beta=0.773)$, factor 3 : pricing $(\beta=0.094)$, factor 6 : payment options $(\beta=0.085)$ factor 5 : restaurant cleanliness $(\beta=0.044)$, and factor 4 : comfort ( $\beta=0.017$ ) ranging from the highest to the lowest contributions.

The fact that some of the factors did not make a large impact on satisfaction and loyalty does not make the dimension insignificant as restaurant image attributes is rather a complex phenomenon and it is quite unrealistic to assume that all variables can account for substantial proportion of variability. Research has also shown that the more a customer visits an environment (for example, a restaurant), the more consumers place some factors in their subconscious level and unless the factors such as employee presence and convenience causes a substantial (negative or positive) surprise, a customer will not notice it (Spies, Hesse \& Loesch, 1997). This theory is embedded in Kano's quality model and more specifically, the basic needs dimension (must-be-needs) (Zhang \& Von Dran, 2002). Basic needs are the minimum attributes acceptable to a customer (Shen, Tan \& Xie, 2000) and encompass attributes customers take for granted. Their presence goes unnoticed, but their absence will generate complaints and dissatisfaction. Restaurant satisfaction does not rise with the presence of such attributes (Tan \& Pawitra 2001). These attributes are naturally expected and customers normally do not verbalise (Matsler \& Hinterhuber, 1998) or explicitly demand them (Martensen \& Gronhøldt, 2001).

\section{Reliability and Validity}

Coefficient Cronbach alpha values were computed for each variable and the total scale on restaurant image attributes. The standardised Cronbach alpha computed for the scale was 0.956 . The Cronbach alpha showed a small decrease in value compared to the pilot study (0.945) which is largely attributed to the scale purification process. The Cronbach alpha values for each dimension ranged from 0.712 to 0.943 . The overall scale reliability and the reliability for each dimension were satisfactory as they were above the acceptable benchmark level of 0.70 (Malhotra, 2004). Table 6 provides an overview of the reliability value for the overall scale and the six dimensions of restaurant image attributes. 
Table 6: Item Reliability Analysis

\begin{tabular}{|l|c|c|}
\hline Factors & $\begin{array}{c}\text { Number } \\
\text { of items }\end{array}$ & $\begin{array}{c}\text { Cronbach } \\
\text { alpha }\end{array}$ \\
\hline Factor 1: Atmospherics & 13 & 0.943 \\
\hline Factor 2: Service & 5 & 0.712 \\
\hline Factor 3: Pricing & 5 & 0.808 \\
\hline Factor 4: Comfort & 3 & 0.890 \\
\hline Factor 5: Cleanliness & 3 & 0.810 \\
\hline Factor 6 : Payment & 2 & 0.843 \\
\hline Overall Cronbach alpha $=0.942$ & \multicolumn{2}{|l}{} \\
\cline { 1 - 3 }
\end{tabular}

Three forms of validity tests were performed, namely content, convergent and predictive validities. The methods of assessing the various types of validity are discussed. The content validity was ascertained by pre-testing the questionnaire with ten respondents and performing a review of the questionnaire by four academics. In addition, a pilot study was undertaken with 50 respondents in order to establish the initial reliability of the questionnaire. This phase of testing involved the computation of the Cronbach alpha coefficient of the overall scale. The scale's convergent validity was assessed for statistical significance by using Pearson's correlation coefficients (Cooper \& Schindler, 2006). A scale's convergent validity is related to the high association between new constructs and other similar constructs. Based on the coorelations there is evidence of convergence regading the six factors with satisfaction and loyalty. The results of the multiple regression analysis provide evidence of predictive validity whereby a moderate to strong predictive relationship was found between restaurant image attributes satisfaction and loyalty.

\section{Recommendations}

The results of the study indicate that restaurateurs generally understand their customers. However, in order to remain competitive in the market, restaurateurs should realise that customers are becoming more discerning, so that they need to implement image attribute enhancement strategies to lure customers to their restaurants. Careful consideration should be taken of factors that may influence the consumer's choice in restaurant selection. Ambience or atmospherics is one of the main reasons why customers return to a restaurant. Impressive atmospherics increase the word-of-mouth probability and increase the potential of turning new customers into loyal clients. Customers would not recommend a restaurant to a friend if they do not find the atmosphere appealing to their own tastes.

Restaurateurs should plan carefully for which market they sell their image to. By conducting restaurant research, by means of a satisfaction/service experience and image questionnaire after a meal, restaurants can determine what is needed to improve the image as well as what type of customers currently patronise their restaurant. The results obtained from the study may assist with the decision-making process to determine which market to target and which atmosphere fit that type of market.

Restaurants should ensure that they have well trained staff that possesses extensive product knowledge to serve customers. Restaurant staff should be able to assist the customer with their needs and answer any question about the menu or facilities available. Staff needs to act like sales people, meeting and greeting customers, providing them with a customised service. The dining experience will not be a great satisfying experience if the first contact is unsatisfying or unprofessional. Restaurant staff should also have personal attributes such as good grooming habits and a clean appearance. In essence, meeting a customer's service expectations will increase the probability of return patronage and recommendations to others. Furthermore, a tourism and skills audit conducted by the Tourism, Hospitality and Sport Education and Training Authority (THETHA, 2007) identified training of staff on service experience as an essential component in the provision of world-class service among restaurants affirm the need for training of staff within this sector.

A restaurant will not succeed unless it can provide good quality food at a reasonable price. Customers tend to evaluate a restaurant's offering on the basis of the price and the food they receive. By having a clear understanding of the market's needs, restaurants can offer a menu with a unique selling proposition based on price and value benefits. Customers are often not willing to revisit a restaurant when they believe that the prices on the menu are unreasonably high (Kim, Lee \& Yoo, 2006). Restaurants should ensure that their customers are comfortable while seated. There should be sufficient space for them to move at the dining table and the seats should be comfortable. When a customer is uncomfortable while dining, he/she will have a negative experience and this could result in decreased satisfaction and loyalty levels as well as a negative word of mouth communication. 
Restaurant atmospherics, service personnel, pricing, payment options, comfort and overall cleanliness of the environment relate to customer satisfaction and have a strong relationship between them. Since elements of décor are likely to differentiate a specific restaurant from its competitors (Menon \& Kahn, 2002), restaurateurs should allocate resources in order to enhance its décor. In order to induce high levels of loyalty a restaurant needs to focus on the satisfaction levels of customers which are influenced by the strong relationships between the environmental factors that are present. In essence restaurants should be a home-away-from-home to a customer.

\section{Limitations and Implications for Future Research}

A combination of quantitative and qualitative research methods is recommended for future research. By using, for example, observational or experimental research methods, rich information can be obtained regarding customers while they dine. Future research should be conducted which expands this study to include demographic subcultures, social classes and lifestyle factors.

The current study concentrated on current customers who patronised restaurants. Those customers who have defected were not included in the study and hence may have other opinions regarding image attributes of the restaurants covered under the study. A notable limitation of the study is that the survey was limited to one region only (Southern Gauteng, South Africa). Further research should attempt to replicate the study to other regions and more restaurants. Such an exercise would enable researchers to further establish the robustness of the scale. Therefore, caution should be taken when interpreting these results as they cannot be accepted as completely relevant to broader geographic locations. A comparison of different types of restaurants, for example those with a high presence of image attributes with those low image attributes may yield interesting results.

\section{Conclusion}

The study provided insights into the dimensions of image attributes in restaurants and the relationship with satisfaction and loyalty. The findings in this research revealed that there are many attributes to consider when designing restaurants and which attributes are important in meeting customer expectations. Whilst dining experiences may be varied, the study provides some practical implications to the restaurant industry in Southern Gauteng which may assist restaurateurs to determine which restaurant attributes are important to their target customers to meet customers' expectations.

Careful consideration should be taken when atmospheric and aesthetic combinations are deliberated in the design of restaurants. Service delivery is a key factor contributing to the overall satisfaction levels. In order to remain competitive in the market, restaurateurs should realize that customers are becoming more discerning which requires them to implement image attribute enhancement strategies to lure customers to their restaurants. By improving a restaurant's image through its various components, a significant positive effect on satisfaction and loyalty levels can be achieved.

\section{References}

Andaleeb, S. S., \& Conway C. (2006). Customer satisfaction in the restaurant industry: an examination of the transaction-specific model. Journal of Service Marketing, 20(1), 3-11.

Bitner, M. J. (1992). Servicescapes: The impact of physical surroundings on customers and employees. Journal of Marketing, 56, 57-71.

Bloemer, J., \& Ruyter, K. (1998). On the relationship between store image, store satisfaction and store loyalty. European Journal of Marketing, 32(5/6,499-513.

Burt, S., \& Carralero-Encinas, J. (2000). The role of store image in retail internationalisation. International Marketing Review, 17(4/5), 433-453.

Carpenter, J. M., \& Moore, M. (2006). Consumer demographics, store attributes, and retail format choice in the US grocery market. International Journal of Retail and Distribution Management, 34(6), 434-452.

Chow, I. H. S., Lau, V., Lo, T.W.C., Sha, Z., \& Yun, H. (2007). Service quality in restaurant operations in China: decision-or experimential-oriented perspectives. International Journal of Hospitality Management, 26(3), 698-710.

Clarke, I., Hallsworth, A., Jackson, P., Kervenoael, R., Perez-Del-Aguila, R., \& Kirkup, M. (2004). Retail competition and consumer choice: contextualizing the "food desserts" debate. International Journal of Retail and Distribution Management, 32(2), 89-99.

Cooper, D.R., \& Schindler, P.S. (2006). Marketing research. 9th ed. Singapore: McGraw-Hill.

Countryman, C.C., \& Jang, S. (2006). The effects of atmospheric elements on customer impression: the case of hotel lobbies. International Journal of Contemporary Hospitality Management, 18(7), 534-545.

Darley, W. K., \& Lim, J. (1999). Effects of store image and attitude toward second-hand stores on shopping frequency and distance travelled. International Journal of Retail and Distribution Management, 27(8), 311-318. 
Dhurup, M., \& Oosthuyzen, A. (2010). Salient store image attributes in consumer store selection decisions and the relationship with store satisfaction and loyalty. Journal of Contemporary Management, 1(7), 380-401.

Erdem, O., Oumlil, A.B., \& Tuncalp S. (1999). Consumer values and the importance of store attributes. International Journal of Retail and Distribution Management, 27(4), 137-144.

Grobler, S. F. (2008). Measuring the impact of perceived quality of services amongst restaurant consumers in Johannesburg. Masters Dissertation University of Johannesburg, Johannesburg.

Hair, J. F., Bush, R. P., \& Ortinau, D.J. (2000). Marketing research: a practical approach for the new millennium. Singapore: McGraw Hill.

Han, H.., Back, K. J., \& Barrett, B. (2009). Influencing factors on restaurant customers' revisit intention: the roles of emotions and switching behaviour. International Journal of Hospitality Management. 19(8/9), 563-572.

Han, H., \& Ryu, K. (2009). The role of the physical environment, price perceptions, and customer satisfaction in determining customer loyalty in the restaurant industry. Journal of Hospitality and Tourism Research, 33(4), 487-510.

Herrington, J. D., \& Capella, L.M. (1996). Effects of music in service environments: a field study. Journal of Service Marketing, 10(2), 2641.

Heung, V. C. S., \& Gu, T. (2012). Influence of restaurant atmospherics on patron satisfaction and behavioural intentions. International Journal of Hospitality Management, 31(4), 1167-1177.

$\mathrm{Hu}, \mathrm{H} .$, \& Jasper, C. R. (2006). Social cues in the store environment and their impact on store image. International Journal of Retail and Distribution Management, 34(1), 25-48.

Jin, B., \& Kim, J. (2003). A typology of Korean discount shoppers: shopping motives, store attributes, and outcomes. International Journal of Service and Industrial Management, 14(4), 396-419.

Kara, A., Kaynak, E., \& Kucukemiroglu, O. (1997). Marketing strategies for fast-food restaurants: a customer view. British Food Journal, 9(9), 318-324.

Kim, W., Lee, Y., \& Yoo, Y. (2006). Predictors of relationship quality and relationship outcomes in luxury restaurants. Journal of Hospitality and Tourism Research, 30,143-169.

Kivela, J. J. (1997). Restaurant marketing: selection and segmentation in Hong Kong. International Journal of Contemporary Hospitality Management, 9(3), 116-123.

Kivela, J., Inbakaran, R., \& Reece, J. (1999). Consumer research in the restaurant environment, part 1: a conceptual model of dining satisfaction and return patronage. International Journal of Contemporary Hospitality Management, 11(5), 205-222.

Ko ,E., \& Kincade, D.H. (1997). The impact of quick response technologies on retail store attributes. International Journal of Retail and Distribution Management, 25(2), 90-98.

Koo, L.C., Tao, F. K. C., \& Yeung, J. H. C. (1999). Preferential segmentation of restaurant attributes through conjoint analysis. International Journal of Contemporary Hospitality Management, (5), 242-253.

Kotler, P. (1974). Atmospherics as a marketing tool. Journal of Retailing, 49(4), 48-64.

Lee, S.L., Ibrahim, M. F, Hsueh-Shan, C. (2005). Shopping-centre attributes affecting male shopping behaviour. Journal of Retail \& Leisure Property, 4(4), 324-340.

Malhotra, N. K. (2007). Marketing Research: An applied orientation. $7^{\text {th }}$ ed. Engle Wood Cliffs, NJ. Prentice Hall.

Martensen A., \& Grønholdt, L. (2001). Using employee satisfaction measurement to improve people management: an adaptation of Kano's quality types. Total Quality Management, 12(7/8), 949-957.

Martineau, P. (1958). The personality of the retail store. Harvard Business Review, 36, 47-55.

Matsler, K., \& Hinterhuber, H. H. (1998). How to make product development projects more successful by integrating Kano's model of customer satisfaction into quality function deployment. Technovation, 18(1), 25-38.

Mawson, E., \& Fearne, A. (1996). Purchasing strategies and decision-making processes in the food service industry: a case study of UK restaurant chains. Supply Chain Management International Journal, 1(3), 34-41.

Menon, S., \& Kahn, B. (2002). Cross-category effects of induced arousal and pleasure on the Internet shopping experience. Journal of Retail, 78, 12-31.

Milliman, R. E., \& Fugate, D. L. (1993). Atmospherics as an emerging influence in the design of exchange environments. Journal of Marketing Management, 3(1), 66-74.

Moolman, H. M. (2011). Restaurant customer satisfaction and return patronage in a Bloemfontein Shopping Mall. Acta Commercii, 4 , 129-146.

Moore, M., \& Carpenter, J. (2006). The effect of price as a marketplace cue on retail patronage. Journal of Product and Brand Management, 15(4), 265-271.

Ness, M., Gorton, M., \& Kuznesof, S. (2002). The student food shopper. British Food Journal, 104(7), 506-525.

Newberry, C. R., Klemz., B. R., \& Boshoff, C. (2003). Managerial implications of predicting purchase behaviour from purchase intentions: A retail patronage case study. Journal of Service Marketing, 17(6), 609-620.

Paulins, V. A., \& Geistfeld, L.V. (2003). The effect of consumer perceptions of store attributes and apparel store preference. Journal of fashion Marketing and Management, 7(4), 371-385.

Pedraja, M., \& Yagüe, J. (2001). What information do customers use when choosing a restaurant? International Journal of Contemporary Hospitality Management, 13(6), 316-318.

Porter, S. S., \& Claycomb, C. (1997). The influence of brand recognition on retail store image. Journal of Product and Brand Management, 6(6), 373-387. 
Pratten, J. D. (2003). The importance of waiting staff in restaurant service. British Food Journal, 105(11), 826-834.

Robinson, C., Abbott, J., \& Shoemaker, S. (2005). Recreating cheers: an analysis of relationship marketing as an effective marketing technique for quick-service restaurants. International Journal of Contemporary Hospitality Management, 17(7), 590-599.

Republic of South Africa (2004). Liquor Act, 2003. No 59 of 2003. Government Gazette, 466 (No. 26924). Cape Town: Government Printers.

Republic of South Africa National Department of Tourism. (2011). National tourism sector strategy. Pretoria: Department of Tourism.

Statistics South Africa. (2013). Food and beverages; December, 2012. Pretoria: Statistics South Africa. [online]. http://www.statssa.gov.zal. (18 June 2013)

Theta (Tourism, Hospitality and Sport Education and Training Authority). (2007). Tourism and Sport Skills Audit. [online]. Available at: http://www.theta.org.zal.(18 June 2013)

Shen, X.X., Tan, K. C, Xie, M. (2000). An integrated approach to innovative product development using Kano's model and QFD. European Journal of Innovation Management, 3(2), 91-99.

Sieders , K., \& Costley, C.L. (1994). Price awareness of consumers exposed to intense retail rivalry: A field study. Advances in Consumer Research, 21, 79-85.

Soriano, D.R. (2002). Customers' expectation factors in restaurants: The situation in Spain. International Journal of Quality and Reliability Management, 19(9), 1055-1067.

Spies, K., Hesse., F., \& Loesch, K. (1997). Store atmosphere, mood and purchasing behaviour. International Journal of Research in Marketing, 14(1), 1-17.

Tan, K. C., \& Pawitra, T. A. (2001). Integrating SERVQUAL and Kano's model into QFD for service excellence development. Management Service Quality, 11(6), 418-430.

Tepeci, M. (1999). Increasing brand loyalty in the hospitality industry. International Journal of Contemporary Hospitality Management, 11(5), 223-230.

Thompson, K. E, Chen, Y.L. (1998). Retail store image: a means-end approach. Journal of Marketing Application Science, 4(6), 161 173.

Wakefield, K. L., \& Blodgett, J. G. (1996). The effect of the servicescapes on customers' behavioural intentions in leisure service settings. Journal of Service Marketing, 10(6), 45-61.

Yavas, U. (2003). A multi-attribute approach to understanding shopper segments. International Journal of retail and Distribution Management, 31(11), 541-548.

Yun, Z., \& Good, L.K. (2007). Developing customer loyalty from e-tail store image attributes. Management and Service Quality, 17(1), 422.

Zhang, P., \& Von- Dran, G.M. (2002). User expectations and rankings of quality factors in different web site domains. International Journal of Electronic Commerce, 6(2), 9-33. 